\title{
Effects of structural injure in the bile bacterial contamination after balloon transduodenal sphincteroplasty (papillary dilation) in dogs ${ }^{1}$
}

\author{
Efeitos da lesão estrutural na contaminação bacteriana biliar após a esfincteroplastia \\ transduodenal (dilatação papilar) em cães
}

\author{
Martin Zavadinack Netto², Djalma José Fagundes ${ }^{3}$, César Orlando Peralta Bandeira² \\ 1. Research from Post-graduate Program in Surgery and Experimentation of Federal University of São Paulo (UNIFESP), Brazil. \\ 2. PhD, Associate Professor of Surgery Department, State University of Maringá, Paraná, Brazil. \\ 3. Associate Professor of Surgery Department, Coordinator of Post-graduate Program in Surgery and Experimentation, UNIFESP, Brazil.
}

\begin{abstract}
Purpose: To evaluate, in dogs, the biliary sphincter subjected to dilation by hydrostatic balloon by the point of view of structural alterations of the papilla and the biochemestry and bacterial contamination of the bile. Methods: Twenty dogs were submitted to laparotomy, duodenotomy, and enlargement of the major duodenal papilla- GA(n=10) - with balloon of $8 \mathrm{~mm}$ inflated with pressure of $0,5 \mathrm{~atm}$, during 2 minutes or to the sham procedure - GB(n=10). Blood samples collected on times t(0day), t(7days) and t(28days) were subjected to dosages of alkaline phosphatase (ALP) and gammaglutamyltransferase (GGT) for cholestasis evaluation. The collected material from the gall bladder at the same times were registered and numbered to be submitted to culture in BHI, blood agar (rich, non-selective element) and Mac Conkey (selective element for Gram-negative bacillus. On the $28^{\text {th }}$ day three fragments of the papilla were tranversally cut by the choledoc axis 3mm from the duodenal papilla and the cuts, stained with hematoxylin-eosin and Masson's tricome, were evaluated according to their inflammatory reaction. Results: The GGT and ALP averages on the three periods in the groups A and B did not show significant differences, not being characterizes the cholestasis. The bacterian contamination was significantly higher in GA $(2,19)$ than in GB $(1,96)$; the contamination was lower in the initial time compared with 7 and 28 days ( $\mathrm{t} 0<\mathrm{t} 7$ and $\mathrm{t} 28)$ in GA and GB $(\mathrm{t} 0<\mathrm{t} 28)$. The chronic inflammatory alteration of the mucosa occurred in $60 \%$ of the GA animals and in $80 \%$ of the GB animals. There was not mural inflammation. Conclusion: The duodenal papilla dilation or its simple manipulation leads to the bacterial contamination of the gall bladder, not associated with cholestasis. The morphologic lesions are more intense in the late phase, not associated with an eventual papilla esthenosis.
\end{abstract}

Key words: Sphincterotomy, Transhepatic. Sphincter of Oddi. Dogs.

\section{RESUMO}

Objetivo: Avaliar, em cães, a papila duodenal maior submetida à dilatação por balão hidrostático sob o ponto de vista das alterações estruturais da papila e da bioquímica e contaminação bacteriana da bile. Métodos: Vinte cães foram submetidos a laparotomia, duodenotomia, dilatação da papila maior - GA (n=10) - com balão de 8mm insuflado com pressão de 0,5atm, durante 2 minutos ou ao procedimento simulado - $\mathrm{GB}(\mathrm{n}=10)$. Amostras de sangue coletadas nos tempos t(0dia), t(7dias) e $\mathrm{t}$ (28dias) foram submetidas às dosagens da fosfatase alcalina (FA) e gama-glutamil-transferase (GGT) para avaliação da colestase. Material colhido da vesícula biliar nos mesmos tempos foi registrado e numerado para ser submetido à cultura em BHI, ágar sangue (meio rico não seletivo), e Mac Conkey (meio seletivo para bacilos Gram-negativos). No 28․ dia três fragmentos da papila forma cortados transversalmente ao eixo do colédoco a $3 \mathrm{~mm}$ da papila duodenal e os cortes corados em hematoxilina-eosina e tricômio de Masson e avaliados quanto a reação inflamatória. Resultados: As médias da GGTe da FA nos três períodos nos grupos A e B não mostraram diferenças significantes, não sendo caracterizada a colestase. A contaminação bacteriana foi significante maior em GA(2,19) que no GB(1,96); a contaminação foi menor no tempo inicial em relação aos 7 e 28 dias( t0<t7 e t28) no GA e no GB (t0<t28). A alteração inflamatória crônica da mucosa ocorreu em $60 \%$ dos animais do GA e em 80\% do GB. Não houve inflamação mural. Conclusão: A dilatação da papila duodenal ou a sua simples manipulação leva a contaminação bacteriana da vesícula biliar, não associada à colestase. As lesões morfológicas são mais intensas na fase aguda e não correspondem a lesões crônicas mais extensas na fase tardia, não estando associadas a uma eventual estenose da papila.

Descritores: Esfincterotomia Transhepática. Esfíncter da Ampola Hepatopancreática. Cães. 


\section{Introduction}

The endoscopic papilotomy is used successfully in the treatment of stones of biliary ductus. However the action upon the duodenal papilla creates a gradual negative pression that allows the duodenal-biliary reflux $^{1,2}$. This reflux has been blamed for the bacterial colonization of the bile with consenquential cholangitis crisis and primary formation of stones, reaching tolls of up to $24 \%$ of complications in the clinic long-range evaluations ${ }^{3,4}$. With the advent of the minimally invasive surgery the indications of intervention on the duodenal papilla received new stimulation. Considering the risk of complications there has been a search for less agressive alternatives $^{5}$. The papilla dilation using a hydrostatic balloon came as an option as efficient as the papilotomy, with the advantage of a lower harming of the functional capacity by the smaller reduction of the basal pressure of the sphincter. This eventual advantage of the dilation that is attributed, on a last thought, by the lower structural lesion of the papilla, is not well characterized in experimental or clinical studies ${ }^{6,7}$. The purpose of this research was to verify the aspects of the histologic alterations of the papilla, biochemical alterations and of bacterial contamination of the bile involved on the transduodenal dillatation of the papilla, with balloon, in a animal experimentation model.

\section{Methods}

The experimental protocol was approved by the Ethics Committee of the Federal University of São Paulo - Escola Paulista de Medicina (UNIFESP - EPM), ratified and developed at the Central Bioterium of Maringá State University (UEM). All the procedures followed, rigorously, the existent regulations about animal experimentation. Twenty adult male dogs, average weigth of $12,5 \mathrm{Kg}$, with state of health comproved by veterinaries from the UEM Vivarium, were kept in ambient and diet proper for the species and under controlled ambient. The group $A(n=10)$ was submitted to a operatory procedure of dilation of the major duodenal papillawith use of hydrostatic balloon and the group $B(n=10)$ was submitted to the operatory procedure without the dilation. All the procedures were done under general anaesthesia, with spontaneous ventilation, using xylasine $2 \%(3 \mathrm{mg} / \mathrm{Kg})$, sodium thiopental 2,5\% (4mg/Kg) and infusion of sodium chloride $0,9 \%(20 \mathrm{ml} / \mathrm{Kg})$ in a superficial vein of the anterior member. In conditions of asepsy and antisepsy it was done a medium laparotomy. The major duodenal papilla was found after longitudinal opening of the descending part of duodenum and the 10 animals of the group A were subjected to dilation of the billiary sphincter. A guide wire was introducted in the biliar duct through the papilla, permitting the passage of a catheter with an external diameter of 2,33 $\mathrm{mm}$ and a balloon with $3 \mathrm{~cm}$ extention and able to reach $8 \mathrm{~mm}$ diamater when inflated. Iodinated contrast solution at 30\% was injected to inflate the balloon, during thirty seconds, until it reached pressure of $380 \mathrm{mmmHg}$, which was kept during two minutes and after that the contrast was withdrawn in
30 seconds. In the last minute of inflation it was done a radiography to evaluate the degree of distention of the balloon in the papilla region. The major duodenal papilla and the choledoc duct of the ten animals of group $B$ (sham) were permeated by the non-inflated balloon catheter, which remained in the choledoc duct during three minutes to simulate the dilation. Once the catheter was removed, these animals were, just like the ones in group A (dilation), immediatly evaluated to check their basal pressure, contraction amplitude and choledoc duct pressure. After seven days (t7) and twenty-eight days (t28) the animals were subjected to another intervention for the simple collection of bile and biochemical dosages. The material gathered from the gall bladder during the operatory act of the first, second and third interventions was registered and numbered to be subjected to culture in BHI (Brain and Heart Infusion), blood agar blood agar (rich, non-selective element) and Mac Conkey (selective element for Gram-negative bacillus). When there was growth, the bacteria were identified in the systems Bactray III (system for the identification of Gram-negative non glucose fermentative and oxidase positive bacilli), $\mathrm{Rb}$ (system for the identification of Gram-negative glucose fermentative bacilli) plus additional biochemical tests, when the bacteria was not identified by the previous systems. The blood samples collected in the times $\mathrm{t} 0, \mathrm{t} 7$ and t28 were subjected to alkaline phosphatase and gamma-glutamyltransferase (GGT) dosages for the evaluation of the hepatic functional activity, given that it is the enzimes that elevate in the presence of cholestasis. On the $28^{\text {th }}$ day the duodenal segment including papilla and distal choledoc were removed and fixed in formol $10 \%$ for 24 hours. Three fragments were transversally cut to the choledoc axis $3 \mathrm{~mm}$ far from the papilla and emblocked in paraffin. The cuts were stained in hematoxylin-eosin and Masson's tricome and subjected to an evaulation by an histologist, in a blind manner. The inflammatory process was classified between present and ausent, considering the proliferative phenomena characterized by epithelial regeneration and mesenchymal reaction with granulation and fibrosis. Enlargment and shortening of villosity worked as parameters in the characterization of chronic inflammation. The statistic study was performed at the Biostatistic Discipline of the Department of Preventive Medicine of UNIFESP-EPM. According to the nature of the variables it was used non-parametric tests (Friedman, MannWhitney, Fisher). The rejection level for the nullity hypothesis was set at 0.05 or $5 \%(p \leq 0,05)$, and the significant values were marked with an asterisk. 


\section{Results}

TABLE 1 - Animals from group A (with papilla dilation) and group B (sham), according to the average values of gammaglutamyltransferase (GGT) in U/L, evaluated in times t0 (preoperatory), t7 (7 days postoperatory) and t28 (28 days postoperatory)

\begin{tabular}{|c|c|c|c|c|c|c|}
\hline & \multicolumn{3}{|c|}{ Group A } & \multicolumn{3}{|c|}{ Group B } \\
\hline & to & $\mathbf{t} 7$ & t28 & to & $\mathbf{t} 7$ & t28 \\
\hline Average & 1,3 & 1,6 & 2,3 & 2,9 & 2,3 & 2,3 \\
\hline
\end{tabular}

Variance analysis by Friedman's two-ways analysis

$(\mathrm{t} 0 \times \mathrm{t} 7 \times \mathrm{t} 28) \chi^{2}$ crít $=5,99$

Group A $\chi^{2}$ calc $=4,16$

Group B $\chi^{2}$ calc $=2,35$

Mann - Whitney Test

(Group A x Group B) U crít = 23

$\mathrm{t} 0 \mathrm{U}=32,0$

t7 $\mathrm{U}^{\mathrm{calc}}=46,0$

$\mathrm{t} 28 \mathrm{U}_{\text {calc }}^{\text {calc }}=44,5$

TABLE 2 - Animals of group A (with papilla dilation) and group B (sham), according to the average values of alkaline phosphatase in U/L, evaluated in the imediate preoperatory (t0), in the seventh (t7) and twenty-eighth (t28) postoperatory days

\begin{tabular}{|c|c|c|c|c|c|c|}
\hline & \multicolumn{3}{|c|}{ Group A } & \multicolumn{3}{|c|}{ Group B } \\
\hline & to & $\mathbf{t 7}$ & $\mathbf{t} 28$ & to & t7 & t28 \\
\hline Average & 37,8 & 45,2 & 39,8 & 26,4 & 29,8 & 36,1 \\
\hline
\end{tabular}

Variance analysis by Friedman's two-ways analysis

$\left(\mathrm{t} 0 \times \mathrm{t} 7 \mathrm{x}\right.$ t28) $\chi^{2}$ crít $=5,99$

Group A $\chi^{2}$ calc $=1,63$

Group B $\chi^{2}$ calc $=0,38$

Mann - Whitney Test

(Group A x Group B) U crít = 23

t0 $\mathrm{U}_{\text {calc }}=30,0$

t7 $U^{\text {calc }}=26,5$

$\mathrm{t} 28 \mathrm{U}_{\text {calc }}^{\text {calc }}=37,5$

TABLE 3 - Qualitative distribution of bacteria in the bile cultures carried out in the three times: preoperatory (t0), seventh (t7) and twenty-eighth (t28) postoperatory day, in the two groups

\begin{tabular}{|c|c|c|c|c|c|c|}
\hline & \multicolumn{3}{|c|}{ Group A } & \multicolumn{3}{|c|}{ Group B } \\
\hline & to & $\mathbf{t 7}$ & t28 & to & $\mathbf{t} 7$ & t28 \\
\hline & $\mathbf{0}$ & Staph & $\mathbf{0}$ & $\mathbf{0}$ & 0 & $\mathbf{0}$ \\
\hline & $\mathbf{0}$ & 0 & 0 & 0 & Pseud & Pseud \\
\hline & $\mathbf{0}$ & Pseud & 0 & $\mathbf{0}$ & 0 & Pseud \\
\hline & $\mathbf{0}$ & Pseud & Pseud & $\mathbf{0}$ & $\mathbf{0}$ & $\mathbf{0}$ \\
\hline & $\mathbf{0}$ & 0 & Pseud & $\mathbf{0}$ & 0 & $\mathbf{0}$ \\
\hline & $\mathbf{0}$ & $\mathbf{0}$ & Pseud & $\mathbf{0}$ & Pseud & 0 \\
\hline & $\mathbf{0}$ & E. coli & E. coli & $\mathbf{0}$ & 0 & CGP \\
\hline & $\mathbf{0}$ & Pseud & 0 & $\mathbf{0}$ & $\mathbf{0}$ & Pseud \\
\hline & $\mathbf{0}$ & Pseud & Pseud & $\mathbf{0}$ & 0 & Pseud \\
\hline & $\mathbf{0}$ & E. coli & 0 & $\mathbf{0}$ & $\mathbf{0}$ & $\mathbf{0}$ \\
\hline Total & 0 & 7 & 5 & 0 & 2 & 5 \\
\hline
\end{tabular}

E. coli $=$ Escherichia coli Pseud $=$ Pseudomonas sp e aeroginosa Staph $=$ Staphilococcus aureus CGP =Gram-positive cocci.

Variance analysis by Friedman's two-ways analysis

$(\mathrm{t} 0 \times \mathrm{t} 7 \times \mathrm{t} 28) \chi_{2}$ critical $=5,99$

Group A $\chi_{2}$ calculated $=8,67 * \mathrm{t} 0<\mathrm{t} 7$ e $\mathrm{t} 28$

Group B $\chi_{2}$ calculated $=6,33 * \mathrm{t} 0<\mathrm{t} 28$

Mann - Whitney Test

(Group A x Group B) Z critical = 1,96

t0 $\mathrm{Z}$ calculated $=0,00$

t7 $\mathrm{Z}$ calculated $=2,19 *$ Group $\mathrm{A}>\mathrm{B}$

t28 $\mathrm{Z}$ calculated $=0,00$ 
TABLE 4 - Animals from group A (with papilla dilation) and group $B$ (sham), according to the presence or ausence of inflammation in the biliary sphincter

\begin{tabular}{|c|c|c|c|c|}
\hline \multirow[b]{2}{*}{ Group } & \multicolumn{2}{|c|}{ Inflammation } & \multirow[b]{2}{*}{ Total } & \multirow[b]{2}{*}{$\%$ of Presence } \\
\hline & Presence & Ausence & & \\
\hline A & 8 & 2 & 10 & 80,0 \\
\hline B & 6 & 4 & 10 & 60,0 \\
\hline Total & 14 & 6 & 20 & 70,0 \\
\hline
\end{tabular}

Fisher's Exact Test

$\mathrm{P}=0,3142$ or $31,42 \%$
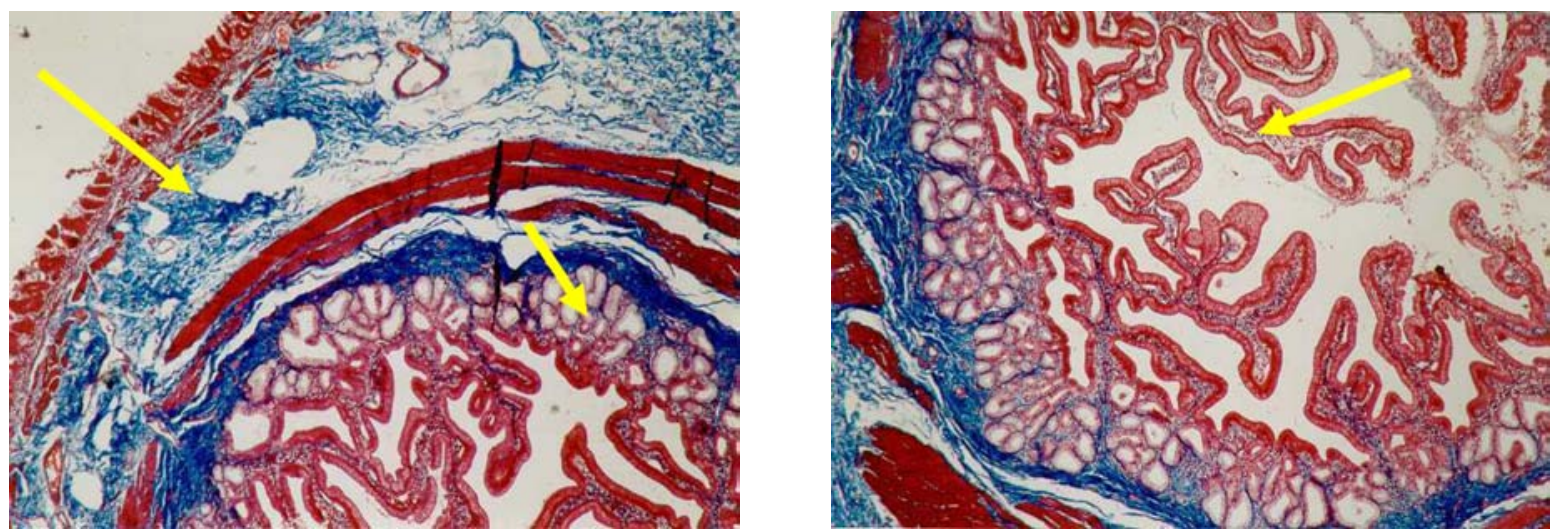

FIGURE 1 - Photomicrographies of transversal cut of the papilla showing on the left the normal aspect in the 28th day after the sham procceding and on the right after the dilation. Duodenal mucosa (big arrow), sphincter (small arrow) and papilla mucosa (arrow head). (Masson 40X)
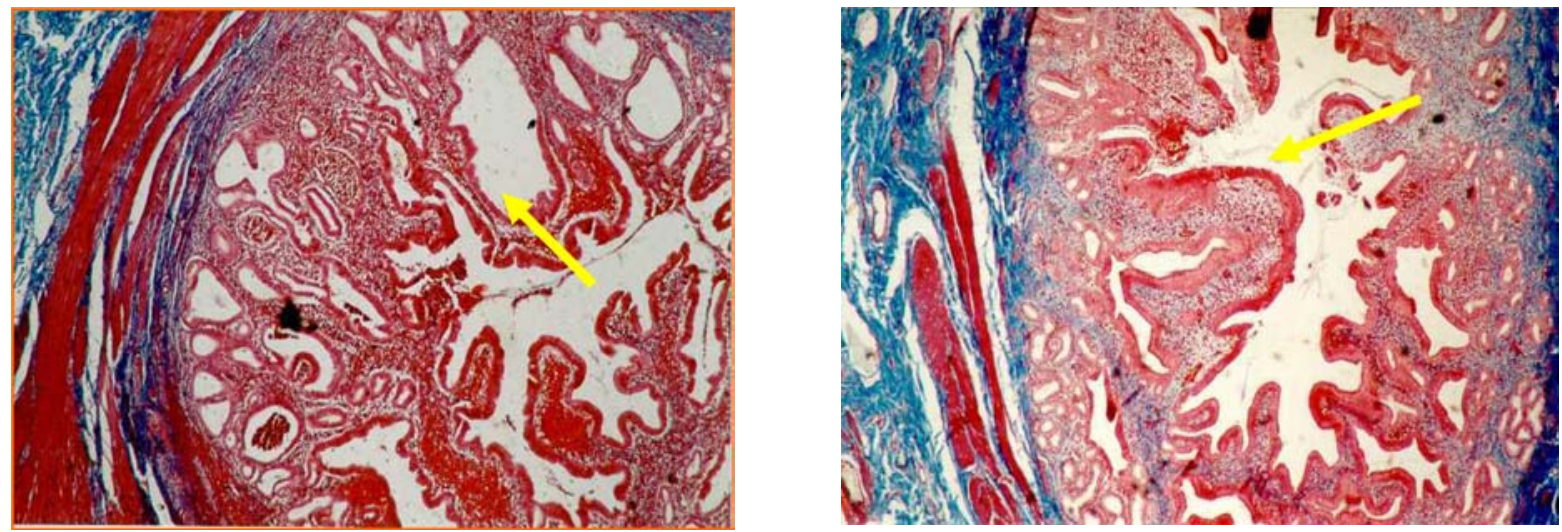

FIGURA 2 - Photomicrographies of a transversal cut of the papilla showing on the left the chronic inflammation of the mucosa (arrow) in the 28th day after the sham procceding and on the right after the dilation (Masson, 40X)

\section{Discussion}

The practice of duodenal papilla dilation with use of balloon leads to functional modifications of the biliary ducts resulting from the morphologic alterations resulting from the procedure. The experimentation in animals allows one to enquationate the study of a series of such modifications. The purpose of the research was the evaluation of the histologic lesion associated with the dilation and the consequences of the cholestasis and the bacterial contamination of the biliary ducts. In the proposed model it was considered to be important the confirmation of the level of dilation. The radiography of the dilating balloon, inflated with iodinated contrast, showed the location of the papilla as a ring constriction, with a bigger proximal insulflattion for being in the duodenum, and distal for being in the choledoc duct, apparently more elastic than the papilla. The model of papilla dilation, with use of balloon, was effective in its intent. There was occurrence of significative variation in the papilla diameter and in the manometry before and after dilation, whose results are discussed at another publication. On what concerns an eventual cholestasis, that 
could be associated to the dilation procedures or the simple manipulation of the duodenal papilla, it was investigated the hepatic enzymes dosage, whose elevation presents high sensibility for the presence of cholestasis such as alkaline phosphatase (ALP) and gamma-glutamyltransferase (GGT). The alkaline phosphatase and GGT dosage showed non significant variations in the various evaluation phases (Tables 1 and 2), even with the suposition of a possible restriction effect to the flux provoked by the inflammatory process from the papilla handling or an eventual duodenal reflux due to the papilla dilation. The GGT dosage showed low values and, eventually, not measurable ones in certain animals. However, it was not noted differences between the groups or between the different evaluation phases. It was not found in the literature similar works in the evaluation of such parameters. The result suggests, however, that there was not cholestasis after the papilla dilation, which is a reason for worry in the clinical practice ${ }^{8}$. It can be inferred that the dilation process or its sham, provokers of trauma and consequentially of an inflammatory process, did not significantly compromise the biliary drainage. The papillary dilation procedure, in the proposed model, showed itself to be very secure in this aspect. The vesicular contents culture tried to evaluate the contamination that could come from the loss of function of the papilla in the reflux contention, given that it was demonstrated, in clinical studies, that the loss of the papillary barrier to the reflux, when the papilotomy is conducted, provoked the persistent contamination of the choledoc duct in $76 \%$ of the 45 studied patients ${ }^{9}$. This contamination seems to be responsible, at least partially, to the late procedures complications that provoke the loss of function of the papilla, as papilotomy and biliodigestive anastomosis ${ }^{10}$. The culture before the procedures was negative in all studied animals (Table 3 ) and in agreement with other literature reports ${ }^{11}$. The culture created one week after the experiment suggests that the dilation is a predisponent factor to contamination, given that there was a significant raise of the number of cases with positive culture in relation to the initial culture and, mainly, because this raise was significantly higher that the one observed in the sham group (Table 3 ). The starting mechanism of such raise in contamination cannot be clarified, since the facilitation of the post-dilation reflux should be associated to the decreasing of the basal pressure of the papilla, which has only occured significantly in the twenty-eighth day, when the contamination had the same incidence as the sham group. A relevant observation with potential practical interest was the progressive raise of the vesicular bile contamination in the successive evaluations of the sham group, considering that, in the third evaluation, the number of positive cultures were of $50 \%$, the same as the group with dilation, both statistically bigger than the initial result (table 3). The finding of the progressive vesicular bile contamination of the animals of the sham group suggests the hypothesis that the repetitive catheterization of the choledoc duct could be a contamination agent, since it seems that the gall bladder has dificulties to eliminate contaminating microorganisms, since there was an interval of three weeks between the last two bile collections. This bile culture evaluation was not done in other experimental works as to permit the comparing of results. Clinically, it was previously demonstrated the possibility of contamination of the choledoc duct by the simple catheterization in retrograde endoscopic cholangiographies. Contamination was verified in $27 \%$ of the bile cultures collected in cholangiographies of patients that had normal choledoc duct or gall bladder stones. On another evaluation, with an interval bigger than 15 months, the percentage of contaminated bile raised to $60 \%{ }^{12}$. The identified bactéria were, in its majority, enterobacteria, identified as Pseudomonas sp and aeruginosa in 14 cultures and Escherichia coli in 3 cultures. Gram-positive cocci were identified in another two cultures. These microorganisms, present in the enteric flora, can provoke the biliary ducts contamination by duodenal reflux or at the passage of catheters to the biliar duct from the duodenum. The presence of bacteria in the gall bladder does not imply the development of an infectious process, but it could have contributed to the upkeeping of the inflammatory process noticed in the papilla of the majority of animals. The experimental investigations should evolve in the evaluation of the biliary ducts contamintion as result of instrumentation, making it possible to find answers that can prevent possibly noxious practices, such as the permanent contamination of biliary ducts, with unforeseeable consequences. Experiments with marked bacteria and serialized cultures, without repeated instrumentalization, will be able to clarify the doubts about the provoking mechanism of the contamination that was observed in this experiment. In the histologic evaluation, there was interest in identifying eventual muscular layer lesion and the inflammatory process in the papilla mucosa, eventually provoked by the balloon distention. Considering the performance of the histologic exam in the twenty-eighth day, the histologic alterations were made of chronic alterations (Figures 1 and 2). The chronic inflammation alteration of the mucosa occurred in $60 \%$ of the animals of the group subjected to dilation and in $80 \%$ of the animals of the sham group (table 4). This inflammatory alteration could be a result of multiple traumas from the passage of catheters, with eventual acute lesions that evolved into a recuperation process. Chronic inflammatory alteration of deeper layers, translated as mural inflammation, was noticed in only one animal of the dilatated group. The mural inflammation was not observed in successive cuts of papilla of this animal, indicating that this is a focal lesion. The histology findings are similar to the ones observed in another paper ${ }^{13}$, in which the observation was conducted in a similar period. The lack of mural inflammation that envolves the own muscular layer, with the exception of the related case, suggests the chances the inflammatory process could evolve to papilla stenosis are low. This was the preocupation in the clinical studies, when the papillas were dilatated with metallic dilatators in operations of choledoc and papilla ${ }^{14}$. The dilation did not provoke muscular rupture, and the occurrence of inflammatory alterations in the papilla mucosa was not statistically divergent from the one observed with the simple catheteraztion of the sham group.

\section{Conclusion}

The dilation of the duodenal papilla or simply its manipulation leads to the bacterian contamination of the 
gall bladder, although it is not associated to cholestase. The morphologic lesions provoked by the dilation or sham are more intense in the acute phase and do not correspond to more extense chronic lesions in the late phase, not being associated with an eventual papilla stenosis.

\section{References}

1. Kawai K, Akasaka Y, Murakami K, Tada M, Kohli Y, Nakajima M. Endoscopic sphincterotomy of the ampulla of Vater. Gastrointest Endosc. 1974; 20(4):148-51.

2. Madura JA; Madura JA; Sherman S; Lehman GA. Surgical sphincteroplasty in 446 patients. Arch Surg. 2005; 140(5):504-11.

3. Ochi Y, Mukawa K, Kiyosawa K, Akamatsu T. Comparing the treatment outcomes of endoscopic papillary dilation and endoscopic sphincterotomy for removal of bile duct stones. J Gastroenterol Hepatol. 1999; 14(1):90-6.

4. Bergman JJGHM, van Berkel A, Groen AK et al. Biliary manometry , bacterial characteristics, bile composition , and histologic changes fifteen to seventeen years after endoscopic sphincterotomy. Gastrointest Endosc. 1997; 45(5):400-5.

5. Cotton PB. Endoscopic retrograde cholangiopancreatography and laparoscopic colecystectomy. Am J Surg. 1993; 165:474-8.

6. Baillie J. Biliary sphincterotomy: less benign than once thought. Curr Gastroenterol Rep. 1999; 1(2):102-6.

7. Staritz M, Ewe K, Meyer zum Büschenfelde K-H. Endoscopic papillary dilation, a possible alternative to endoscopic papillotomy. Lancet. 1982; 1:1306-7.
8. Tarnasky PR, Cunningham JT, Hawes RH, Hoffman BJ, Cotton PB. Pitfalls of bile duct stone removal after balloon sphincter dilation. Am J Gastroenterol. 1996; 91(4):822.

9. Gregg JA, De Girolami P, Carr-Locke DL. Effects of sphincteroplasty and endoscopic sphincterotomy on the bacteriologic characteristics of the common bile duct. Am J Surg. 1985; 149:668-71.

10. Cetta F. Do surgical and endoscopic sphincterotomy prevent or facilitate recurrent common duct stone formation? Arch Surg. 1993; 128:329-36.

11. Queiroz VF. Anastomoses colecistojejunais em Y de Roux, com alças de comprimentos diferentes: estudo experimental em cães. [Tese Doutorado]. São Paulo: Universidade Federal de São Paulo; 1994.

12. Sand J, Airo I, Hiltunen KM, Mattila J, Nordback I. Changes in biliary bacteria after endoscopic cholangiography and sphincterotomy. Am Surg. 1992; 58:324-8.

13. Takahata S, Yokohata K, Nabae T et al. Sphincter of Oddi contractile function after balloon dilation: detailed manometric evaluation in conscious dogs. Gastrointest Endosc. 2000, 52(5):618-23.

14. Smith R. Strictures of the bile duct. Progr Surg. 1971; 9:157-75.

\section{Acknowledgments}

To the journalist Anna Carolina Negrini Fagundes for the English article's translation.

\section{Correspondence:}

Djalma José Fagundes

Rua Camé, 242/244, conjunto 33

03121-020 São Paulo-SP Brazil

Phone: (5511)6604-4408

djfagundes.dcir@epm.br
Conflict of interest: none Financial source: none

Received: April 09, 2006

Review: May 10, 2006

Accepted: June 13, 2006

\section{How to cite this article:}

Zavadinack Netto M, Fagundes DJ, Bandeira COP. Effects of structural injure in the bile bacterial contamination after balloon transduodenal sphincteroplasty (papillary dilation) in dogs. Acta Cir Bras. [serial on the Internet] 2006 SeptOct;21(5). Available from URL: http://www.scielo.br/acb. 